University of Michigan Law School

University of Michigan Law School Scholarship Repository

\title{
Corporate Governance, Capital Markets, and Securities Law
}

\author{
Adam C. Pritchard \\ University of Michigan Law School, acplaw@umich.edu
}

Available at: https://repository.law.umich.edu/book_chapters/193

Follow this and additional works at: https://repository.law.umich.edu/book_chapters

Part of the Business Organizations Law Commons, Legal History Commons, and the Securities Law Commons

\section{Publication Information \& Recommended Citation}

Pritchard, Adam C. "Corporate Governance, Capital Markets, and Securities Law." In The Oxford Handbook of Corporate Law and Governance, edited by Jeffrey N. Gordon and Wolf-Georg Ringe, 1063-83. Oxford Handbooks. Oxford: Oxford University Press, 2018.

This Book Chapter is brought to you for free and open access by the Faculty Scholarship at University of Michigan Law School Scholarship Repository. It has been accepted for inclusion in Book Chapters by an authorized administrator of University of Michigan Law School Scholarship Repository. For more information, please contact mlaw.repository@umich.edu. 
CHAPTER 40

\section{CORPORATE GOVERNANCE, CAPITAL MARKETS, AND SECURITIES LAW}

ADAM C. PRITCHARD

\section{INTRODUCTION}

AT first blush, the connection between corporate governance and capital markets might seem tenuous. Under the Efficient Capital Market Hypothesis (ECMH), investors will incorporate their assessment of a firm's corporate governance into their valuation of the firm's future cash flows and the risk associated with those cash flows. Consequently, a company's stock price will reflect the quality of its corporate governance in limiting agency costs associated with the company's managers and/or controlling shareholders. ${ }^{2}$ On this view, securities regulators' only concern is ensuring that corporate governance terms are accurately disclosed. If disclosure is effective, even unsophisticated investors will be protected. Poor corporate governance-if it is adequately disclosed-will not affect investors' expected returns because the price they pay for a security will be "fair," i.e., discounted to reflect any reduced returns that may result from poor corporate governance. Thus, one can think of securities markets as a grading mechanism for the efficacy of corporate governance.

From its beginnings, however, securities law has sought to do more than neutrally grade corporate governance. Securities law obviously needs to discourage fraud, with its obvious implications for the value of disclosure. (Fraud also has the potential to undermine the market's ability to grade firms' corporate governance provisions.) But securities law has also worried about other forms of overreaching by corporate insiders. Justice Louis Brandeis' oft-quoted phrase that " $\mathrm{s}[\mathrm{]}$ unlight ... is the best disinfectant; electric light the best

\footnotetext{
${ }^{1}$ See Eugene F. Fama, "Efficient Capital Markets: A Review of Theory and Empirical Work", 25 J. Fin. 383 (1970) (surveying theoretical implications of efficient markets and empirical testing of the efficient markets hypothesis).

${ }^{2}$ See Frank H. Easterbrook \& Daniel R. Fischel, "The Corporate Contract", 8g Colum. L. Rev. 1416, 1432 (1989) ("Governance structures are known to anyone seeking the information, so the pricing mechanism will embody their effects for good or ill").
} 
policeman" captures the attitude succinctly. ${ }^{3}$ Disclosure has been justified, not simply as a means of promoting accurate pricing, but also as a means of exposing - and disinfectingproblematic behavior. Exposure would deter wrongdoing by managers and promoters. ${ }^{4}$ Managers bent on self-dealing may restrain themselves if related-party transactions must be disclosed, at least if disclosure is backed by a plausible threat of enforcement. If investors (and perhaps, regulators) can see such activities clearly, then market participants (assuming either a modicum of shame or oversight) are less likely to engage in opportunistic behavior in the first place. ${ }^{5}$

What role should securities law play in encouraging corporate governance standards that hold managers and directors accountable to shareholders? Is disclosure, bolstered by market forces, sufficient to induce efficient corporate governance provisions, as the ECMH suggests? Or should securities law affirmatively seek to put a thumb on the scale of corporate governance outcomes, pushing companies toward "good" corporate governance? From the perspective of those who believe that governance has significant potential to limit agency costs, a disclosure regime-coupled with robust enforcement-that promoted good corporate governance might provide a signal that a company was well run, with structural provisions in place (e.g., independent directors) to keep agency costs in check. If investors value that signal, we have the groundwork for a virtuous circle, with an efficient and effective disclosure regime fueling a potential race to the top in corporate governance.

This argument blurs the line between corporate governance and the disclosure focus of securities law. But another question lurks: Does corporate governance influence the efficiency of securities markets? History suggests it might. Exchanges have long imposed corporate governance mandates on companies listing their shares for trading. Securities regulators, as they have gained greater authority over exchanges, have used listing standards as a tool for promoting more stringent corporate governance standards in the name of promoting "investor confidence," and at least implicitly, liquidity.

There may be limits, however, to the connection between liquidity and corporate governance. In the US, listing standards for public companies have become a favored tool by which the federal government imposes governance standards. Those standards, however, do not always have a clear connection to the efficiency of securities markets. Consequently, it is unclear whether the US model of securities law provides a useful lesson, or a cautionary tale, for other jurisdictions contemplating corporate governance reform.

This chapter explores the dividing line between corporate governance and securities law from both historical and institutional perspectives. Section 2 examines the origins of the dividing line between securities law and corporate governance in the United States, as well as the efforts of the SEC to push against that boundary. That history sets the stage for section 3. which broadens the inquiry by examining the institutional connections between capital markets and corporate governance. Are there practical limits to the connection between

\footnotetext{
3 Louis D. Brandeis, Other People's Money 92 (1913).

4 Troy A. Paredes, "Blinded by the Light: Information Overload and its Consequences for Securities Regulation", 81 Wash. U. L.Q. 417, 464 (2003) ("The strategy of shaming is premised on actively using disclosure to influence corporate conduct").

5 See Paul G. Mahoney, "Mandatory Disclosure as a Solution to Agency Problems", 62 U. Chi. L. Rev. 1047 (1995) (contending that mandatory disclosure works to deter managers from engaging in opportunistic behavior at the expense of shareholders).
} 
securities law and corporate governance? The US again illustrates the point, as Congress has increasingly crossed the traditional boundary between securities law and corporate governance. I conclude by speculating on the future of the dividing line between corporate governance and securities law.

\section{A Brief History of the Dividing Line BETWEEN CORPORATE GOVERNANCE AND The Securities LaW in the United States}

\subsection{Corporate Law and Corporate Governance in the United States}

The US treats corporate governance and securities law as separate spheres. Why not just "company law"? The answer is historical, not functional. Before there were federal securities laws in the US, there were state corporate laws. State corporate law not only gave corporations their legal existence, but also imposed corporate governance mandates for the protection of shareholders and creditors. State corporate law determines most questions of internal corporate governance-the role of boards of directors, the allocation of authority between directors, managers, and shareholders, etc. ${ }^{6}$ The force of those mandates is constrained by the fact that, under US law, companies have unfettered discretion in choosing their state of incorporation. Moreover, the "internal affairs" doctrine requires courts to apply the law of the state of incorporation to corporate law disputes.?

The result of this combination has been an "issuer choice" regime in state corporate law in that US Corporations are free to choose the law of the state that best suits the needs of their directors, managers, and shareholders, without regard to where the corporation principally does business. States can compete to attract firms by offering the most attractive menu of corporate law rules and the best judges for resolving any disputes that may arise. Directors make that choice, subject to the risk that the market will sanction them if they pick a jurisdiction with overly lax standards. Thus, the stage was set early on for an "enabling" or "permissive" model of state corporate law, which progressively diluted a number of the regulatory mandates that were common in early state corporation statutes. First New Jersey, then Delaware, took the lead in attracting corporations headquartered in other jurisdictions, with the principal selling point being the elimination of restrictions on corporate directors and managers that earlier featured prominently in the corporate law of many states. ${ }^{8}$ Defenders

${ }^{6}$ Cort v. Ash, 422 U.S. 66, 84 ("Corporations are creatures of state law, and investors commit their funds to corporate directors on the understanding that, except where federal law expressly requires certain responsibilities of directors with respect to stockholders, state will govern the internal affairs of the corporation").

7 On the history of the internal affairs doctrine, see Frederick Tung, "Before Competition: Origins of the Internal Affairs Doctrine", 32 J. Corp. L. 33 (2006).

8 Curtis Alva, "Delaware and the Market for Corporate Charters: History and Agency", 15 Del. J. Corp. L. 885, 898 (1990). 
of this trend contend that competition in the capital markets compels managers to offer shareholders corporate law rules that effectively constrain the agency costs inherent in the separation of ownership and control. ${ }^{9}$

Even before the adoption of the federal securities laws, there were counterweights to the influence of the states over corporate governance, primarily driven by capital markets. That market-driven response suggests there may be an inherent connection between corporate governance and capital markets. The New York Stock Exchange (NYSE)-the first truly national exchange in the US-provided a contractual version of a national securities law, at least for the US's largest public companies. Through its listing agreement, the NYSE played an important role in promoting both disclosure and improved corporate governance by allowing companies to pre-commit to best practices. Most conspicuously, the NYSE waged a long campaign against the traditional secrecy of corporate managers. ${ }^{10}$ Despite a number of practical obstacles, ${ }^{11}$ the NYSE eventually was able to require listed corporations to provide regular balance sheets and other financial data to stockholders. ${ }^{12}$ The NYSE's requirement that those financial statements be audited also provided a substantial impediment to fraud. ${ }^{13}$

The NYSE's practice of imposing corporate governance and disclosure requirements through listing standards, although purely voluntary (no one could force a company to list its shares), did create a contractual certification mechanism that companies could use to signal their quality. The value of the NYSE's listing requirements is testified by the fact that Congress closely tracked the NYSE disclosure requirements when it drafted the Securities Exchange Act of 1934 (Exchange Act). ${ }^{14}$ The difference, of course, is that the disclosure requirements for public companies became a legal mandate, backed up by SEC enforcement, rather than a contractual undertaking, backed up by the threat of delisting from the exchange. With the advent of that mandate, the stage was set for the dividing line between corporate governance and securities law to have significant consequences because securities law, unlike state corporate law or listing standards, could not be easily evaded.

9 Ralph K. Winter, "State Law, Shareholder Protection, and the Theory of the Corporation", 6 J. Leg. Stud. 251 (1977).

${ }^{10}$ George L. Leffler, The Stock Market 428-29 (1951).

11 The movement toward requiring greater disclosure by listing companies was prolonged by the fact that changes in listing agreements do not work retroactively. Leffler, supra note 10, at 433 ("Companies could be held only to agreements which they had signed; some of these were entered into a great many years ago. If new and additional agreements were formulated by the Exchange, old listed companies could not be compelled to comply except by Exchange persuasion, or if they applied for further listing of stock"); Michael E. Parrish, Securities Regulation and the New Deal 40 (1970) ("Recommendations by the listing committee were never retroactive"). Until 1939, companies paid a one-time listing fee which gave them the right to a listing in perpetuity. Leffler, supra note 10, at 427. Finally, other exchanges imposed substantially lower listing standards than did the NYSE, and the over-the-counter market imposed none at all. Leffler, supra note 10, at 433 . The combination of these factors undoubtedly reduced the NYSE's bargaining leverage with companies in pushing for greater disclosure. More fundamentally, it also suggests that the demand for disclosure among investors was limited.

12 Paul G. Mahoney, "The Exchange as Regulator", 83 Va. L. Rev. 1453, 1469-70 (1997).

13 The policy was adopted in 1928; by 1931, 83\% of listed companies were complying, and in 1932 the NYSE made the policy mandatory for all newly listed companies. See Leffler, supra note 10, at 430 (discussing NYSE's struggle to force companies to submit to independent audits).

${ }^{14}$ George J. Benston, "Required Disclosure and the Stock Market: An Evaluation of the Securities Exchange Act of 1934", 63 Am. Econ. Rev. 132, 133 (1973). 


\subsection{The Introduction of the Federal Securities Laws}

The gradual relaxation of corporate governance mandates in state corporate law was not without its detractors, then or now. Critics of issuer choice argue that states were competing for charter fees-soliciting "tramp" corporations-by pandering to corporate managers. The incentive for the states to compete for charters is clear. Delaware, as the long-term winner of that competition for corporate charters, ${ }^{15}$ currently funds roughly a quarter of its state budget from corporate charter fees.$^{16}$ Critics of issuer choice charge that states prevail in this competition by leaving shareholders vulnerable to overreaching by corporate managers. Exchange listing requirements are an insufficient counterweight, on this view, because exchanges are similarly beholden to corporate managers. The result, critics alleged, has been a "race to the bottom."17

The obvious answer to concerns raised by a potential "race to the bottom" was federal minimum standards, but at one time, the federal structure of the US government was thought to limit the federal government's power over corporate governance. As the US confronted the economic devastation wrought by the stock market crash of October 1929 and the ensuing Great Depression, corporate governance was seen as the province of the states, whose corporate laws gave corporations their very existence. Thus, the scope of the federal intervention was necessarily constrained, the policy levers available were limited.

There was some support among more radical New Deal reformers for a "federal corporate law." The interventions that Franklin Delano Roosevelt would ultimately pursue were more targeted, however, as his administration was reluctant to push constitutional limits. As we shall see, those limits were soon abandoned. By the end of the Second World War, the constitution was no longer a meaningful constraint on the power of the federal government to dictate corporate governance standards. The dividing line fostered by those now-discarded constitutional doubts, however, persists in the US as a matter of tradition and interpretive presumption. Even today, state corporate law determines most internal governance questions while federal securities law is generally limited to governing questions of disclosure to shareholders-annual reports, proxy statements, and periodic filings.

The push to enact federal securities law was one of the great political battlegrounds of the New Deal; 1933 to 1935 saw annual fights to enact the three laws that established the foundation of federal securities legislation. The first, the Securities Act of 1933 (Securities Act), brought the federal government into the regulation of the public offering of securities, curbing the investment bankers' prior domination of that process. The law required corporate issuers to make full disclosure when selling securities. The second, the Exchange Act, required disclosure of operations and results by companies listing on exchanges, as noted above. Although the Exchange Act targeted the NYSE, particularly in regulating broker-dealers, the NYSE did get one benefit from the law: The Exchange Act's mandate

\footnotetext{
15 According to the Delaware Secretary of State, $83 \%$ of U.S. IPOs in 2013 were incorporated in Delaware, along with more than half of all public companies and $65 \%$ of the Fortune 500 . Delaware is the Jurisdiction of Choice for U.S. IPOs, Delaware Corporate and Legal Services Blog (June 2, 2014), available at http://decals.delaware.gov/2014/06/02/delaware-is-the-jurisdiction-of-choice-for-u-s-ipos/.

16 Delaware Division of Corporations, 2012 Annual Report, at 2 (reporting that division collected “ $\$ 867.2$ million dollars in fiscal year (FY) 2012 and accounted for $26 \%$ of the State's general fund").

17 William Cary, "Federalism and Corporate Law: Reflections Upon Delaware", 83 Yale L. J. 663 (1974).
} 
for disclosure by listed companies eliminated the ability of rival exchanges to undercut the NYSE's disclosure requirements. The NYSE's gold-plated standards would be mandated for all listed companies, although companies that traded in the over-the-counter market remained exempt for another 30 years. These two laws cemented disclosure as the foundational basis of the securities law.

The third foundational securities law, the Public Utility Holding Company Act of 1935 (PUHCA), departed from the disclosure model underpinning the Securities Act and the Exchange Act, making it the most controversial of the three securities laws from FDR's first term. ${ }^{18}$ PUHCA targeted the holding companies that owned most of the public utilities in the US at the time. The public utility structure had long been a bette noire of reformers; the collapse of the Insull public utility holding company was the Enron of its day. ${ }^{19}$ The demise of the Insull empire cemented the public utility holding company structure's reputation for abuse.

Given that the holding companies sprawled across multiple jurisdictions, no state could effectively control their corporate governance. Disclosure was not enough to correct the abuses. If regulatory oversight of these monopolies was to be effective, stronger medicine was required: The federal government needed to control corporate governance. The economic crisis provided Roosevelt with the opportunity to eliminate the holding companies. On January 4, 1935, Roosevelt called for the "abolition of the evil of holding companies" in his State of the Union address to Congress. ${ }^{20}$ The public utilities industry was considerably less enthusiastic about being the subject of the federal government's experiments in corporate governance, predicting economic disaster if the bill were enacted. ${ }^{21}$

PUHCA went well beyond the disclosure mandates of the two earlier securities statutes. PUHCA's "death sentence" provision effectively limited utility holding companies to one geographic area; those that did not comply were to be broken up under the direction of the SEC. ${ }^{22}$ The death sentence provision was a major departure from the disclosure paradigm

\footnotetext{
${ }^{18}$ Joel Seligman has characterized PUHCA as "the most radical reform measure of the Roosevelt administration." Joel Seligman, The Transformation of Wall Street 122 (3d ed. 2003); see also Morris L. Forer, "A Postscript to the Administration of the Public Utility Holding Company Act: The HydroElectric System Case", 45 Va. L. Rev. 1007, 1007-08 (1959) ("Probably the most dynamic piece of New Deal legislation, [PUHCA] was revolutionary in that it required not only the immediate eradication of specific and now all too familiar abuses, but also in that it provided for the minute supervision of actions and programs then conceived as being safely reposed in management. This statute aimed not only at the remedial, but, shooting at the escaping present, had also as its target a better economic future" (footnote omitted)).

19 See David Skeel, Icarus in the Boardroom: The Fundamental Flaws in Corporate America and Where They Came From 8, 80-89 (2005) (discussing Insull); Richard D. Cudahy \& William D. Henderson, "From Insull to Enron: Corporate (Re)Regulation After the Rise And Fall of Two Energy Icons", 26 Energy L. J. 35, 36 (2005).

${ }^{20}$ Quoted in Arthur M. Schlesinger, Jr., "The Age of Roosevelt: 1935-1936", The Politics of Upheaval $305(1960)$.

${ }^{21}$ Wendell Willkie, the president of Commonwealth and Southern (and future Republican presidential nominee), warned that: "the utility industry would be thrown "into a chaos of liquidation and receiverships," holders of utility stocks would suffer "practically complete" losses, and a "great bureaucracy in Washington will be regulating the internal affairs of practically all utility operating companies in the United States." The backers of the death sentence, Willkie charged, were trying "to 'nationalize' the power business of this country." Id. at 310.

${ }^{22}$ Seligman, supra note 18 , at 131.
} 
of the earlier securities laws. The holding company legislation also required registration and disclosure, but it broke new ground in giving the SEC control over the utilities' capital structures and corporate governance as part of their reorganization. Thus, the legislation set a new high water mark for federal interference with business: "Except in wartime, the federal government never before had assumed such total control over any industry."23 PUHCA's sweeping reforms would trigger a decade-long war in the courts, as the giant utilities resisted the efforts of the SEC to dismantle them. But it also set the stage for the SEC to play a key role in corporate governance, albeit for only a portion of American business.

For opponents of federal economic regulation, PUHCA looked like the constitutional test case for the federal control of corporate governance that liberals had long sought. The Roosevelt administration ultimately prevailed despite the industry's resistance, but only after an epic legal struggle, requiring three visits to the Supreme Court before it was finally resolved in the government's favor. ${ }^{24}$ Only a decade after PUHCA's enactment did the Court resolve the constitutionality of the controversial death sentence provision. ${ }^{25}$ When the North American v. SEC decision came down, it was an enthusiastic validation of the SEC's power to break up utility holding companies. The Court's opinion painted with a broad, moralistic brush: "The fact that an evil may involve a corporation's financial practices, its business structure or its security portfolio does not detract from the power of Congress under the commerce clause to promulgate rules in order to destroy that evil." ${ }^{26}$ Under its new understanding of the Commerce Clause, the Court had validated the federal government's authority over corporate governance. Would Congress and the SEC exercise that authority?

The answer was no-at least in the short term. Having gained the power, the federal government lost the will. PUHCA, which in the 1940s allowed the SEC to dictate corporate governance standards to an industry vital to the economy, faded in significance after the nation's public utility holding companies were broken up by the 1950s. It did not prove to be the trial run for "federal corporation law" as liberals had hoped. A generation later, narrow interpretations and regulatory exemptions undid much of the work accomplished by the SEC in breaking up the holding companies. New utility conglomerates emerged, such as Enron, with diverse business interests and sprawling operations. PUHCA's purpose was largely repudiated, and the Act itself was repealed in $2005 .{ }^{27}$ After PUHCA's repeal, the SEC was deprived of the role that gave the agency an important say in corporate governance, limiting the agency to overseeing the disclosure-focused regulation of the Securities Act and Exchange Act.

PUHCA's withering foreshadowed a broader retreat by Congress and the SEC in the realm of corporate governance, and indeed, securities law generally. Congress passed no significant securities legislation between 1940 and 1964. The SEC went from being an activist force in the 1930s, to being a backwater after its wartime move to Philadelphia. (It was not returned

\footnotetext{
23 Schlesinger, supra note 20, at 306.

24 The Court first addressed whether a host of individual challenges to the statute could be stayed pending Supreme Court consideration of a test case. Landis v. North American Co., 299 U.S. 248, 249 (1936). The second case upheld only the constitutionality of the relatively uncontroversial registration and disclosure provisions of PUHCA. Electric Bond \& Share Co. v. SEC, 303 U.S. 419, 442-443 (1938).

25 See N. Am. Co v. SEC, 327 U.S. 686, 704 (1946).

26 Id. at 706. Murphy similarly disposed of the due process clause claim. Id. at 708.

27 Energy Policy Act of 2005, Pub. L. 109-158, 119 Stat. 594.
} 
from exile until 1948.) Simply put, almost as soon as the constitutionality of PUHCA was established in North American, affirming the power of Congress over corporate governance, securities law stopped pushing those boundaries. Not until the 1960 s would that push be revived, but that extension would come from the SEC and the courts, not Congress.

\subsection{The 1960s Expansion}

The 1960 s witnessed a rapid expansion of the influence of the federal securities laws, in the form of broad interpretations of Rule 1ob-5 of the Exchange Act. ${ }^{28}$ Rule 10b-5, which the Commission had adopted two decades earlier under its $\$ 10(\mathrm{~b})$ authority as a general antifraud prohibition, threatened to become an overarching "federal corporation law." 29

The development began with a topic squarely at the intersection of disclosure and corporate governance: insider trading. Informational advantages discourage stock market liquidity, so exchanges and securities regulators have an incentive to check information asymmetry if it is feasible to do so. For that reason, the NYSE and other exchanges have long had (spottily enforced) requirements that listed companies disclose information that was likely to move the market. The intersection with corporate governance arises because use of inside information can be thought of as a misappropriation by the insider of a corporate asset: material, confidential business information. That misappropriation has come to be seen as a breach of fiduciary duty under state corporate law. ${ }^{30}$ The influence of inside information on the securities markets has also attracted the interest of the SEC, however, and that agency has played the starring role in developing the law of insider trading.

The SEC's first salvo came in 1961, when it pioneered prohibitions against insider trading with its Cady, Roberts decision. ${ }^{31}$ The source of the prohibition was somewhat surprising. In Cady, Roberts, the Commission interpreted Rule 10b-5 to prohibit insider trading, despite the fact that neither Rule 10b-5 nor $\$ 10(\mathrm{~b})$ makes any mention of insider trading. Notwithstanding this omission, the SEC found in Cady, Roberts that a director of a public company violated Rule 10b- 5 by tipping non-public information. The director had learned that the company was planning to cut the size of its dividend. The director, who happened to be the partner of a brokerage firm, provided the information to one of his partners at the brokerage house, who traded on it. In concluding that the director had violated Rule 10b-5, the SEC set out a broad fiduciary standard for the insider trading prohibition:

The obligation rests on two principal elements; first, the existence of a relationship giving access, directly or indirectly, to information intended to be available only for a corporate purpose and not for the personal benefit of anyone, and second, the inherent unfairness involved where a party takes advantage of such information knowing it is unavailable to those with whom he is dealing. ${ }^{32}$

28 17 C.F.R. $\$ 240.10 b-5(2002)$.

29 See generally Arthur Fleischer, Jr., "Federal Corporation Law': An Assessment", 78 Harv. L. Rev. 1146 (1965) (arguing that "the growth of federal law in the corporate area is sound," but noting the criticism "that federal law has invaded areas never contemplated by the Congress when adopting the securities acts").

${ }^{30}$ Brophy v. Cities Services Co., 31 Del. Ch. 241, 70 A.2d 5 (1949).

${ }^{31}$ In re Cady, Roberts o Co., 40 S.E.C. 907, 912-913 (1961). $\quad{ }^{32}$ Id. at 912 (footnote omitted). 
This standard was not constrained by state law notions of fiduciary duty. Indeed, Cady, Roberts noted in passing that "the securities acts may be said to have generated a wholly new and far-reaching body of Federal corporation law." 33

The SEC's interpretation is breathtaking in its assertiveness. The fiduciary obligation outlined by the agency finds no support in the text of either Rule 10b-5 or $\$ 10(\mathrm{~b})$. With the Cady, Roberts decision, the SEC gave notice that in interpreting "[the] elements [of $\$ 10(\mathrm{~b})$ ] under the broad language of the anti-fraud provisions we are not to be circumscribed by fine distinctions and rigid classifications." ${ }^{\text {"34 }}$ Thus, the SEC announced its intent to root out information asymmetries in the secondary markets to protect "the buying public" "from the misuse of special information." ${ }^{35}$ The securities laws would be interpreted as needed to achieve that goal; the SEC developing its own body of fiduciary principles, unmoored from statutory text and untethered by state corporate law, to achieve that end. ${ }^{36}$

Three years later in Securities and Exchange Commission v. Capital Gains Research Bureau, Inc., ${ }^{37}$ the Supreme Court gave a green light to the SEC to extend the boundaries of its powers in fleshing out a new-federal-understanding of fiduciary obligation. The Capital Gains decision, although turning on an interpretation of the Investment Advisers Act of $1940,{ }^{38}$ suggested that the SEC could expand its power through agency and judicial interpretation of existing statutes and regulation. The agency would not need to resort to the cumbersome rulemaking process under the Administrative Procedure Act, or, still more daunting, seek legislation. According to the Court, "Congress intended the Investment Advisers Act of 1940 to be construed like other securities legislation enacted for the purpose of avoiding frauds, not technically and restrictively, but flexibly to effectuate its remedial purposes." ${ }^{39}$ After its victory in Capital Gains, the SEC would push an aggressive interpretation of $\$ 10$ (b) of the Exchange Act in the lower courts, particularly the Second Circuit, as its principal weapon in its bold new campaign against insider trading. Four years later, in SEC v. Texas Gulf Sulphur, the Second Circuit would validate the SEC's expansive reading of $\$ 10$ (b) of the Exchange Act. ${ }^{40}$ Capital Gains would be cited by the Texas Gulf Sulphur majority for the proposition that even negligent insider trading would be unlawful. ${ }^{41}$ Post Capital Gains, the SEC and the lower courts could feel confident that their expansive interpretations would be upheld.

By the end of the 1960 s the federal securities laws seemed poised to take over the law governing corporations entirely. In the words of Louis Loss, "the great Rule 1ob-5 . . seems to be taking over the universe gradually." ${ }^{42}$ This usurpation of corporate governance standards was being accomplished by the SEC and the courts without any intervention from Congress.

\footnotetext{
33 Id. at 910 (footnote omitted). $\quad{ }^{34}$ Id. at $912 . \quad{ }^{35}$ Id. at 913.

${ }^{36}$ David S. Ruder, "Pitfalls in the Development of a Federal Law of Corporations by Implication Through Rule 10b-5", 59 Nw. U. L. Rev. 185, 185 (1964) ("Despite Congressional unwillingness to enact a 'federal law of corporations', it now appears that such a law is arising by implication through interpretation of the various securities acts").

37375 U.S. 180 (1963). $\quad 3854$ Stat. 847 , as amended 15 U.S.C. $\$ 8$ ob-1 et seq.

39 Capital Gains, 375 U.S. at 195 (citations and quotations omitted).

$40 \quad 401$ F.2d 833 (2d Cir. 1968) (en banc). $\quad{ }_{41}^{41}$ Id. at 855.

42 Louis L. Loss, "The American Law Institute's Federal Securities Code Project”, 25 Bus. Law. 27, 34 (1969).
} 


\subsection{The 1970s and 1980s: Retrenchment}

The era of 1ob-5 expansionism came to an abrupt halt in the 1970s. The first salvo came in a pair of class actions from the mid-197os-Blue Chip Stamps ${ }^{43}$ and Ernst \& Ernst ${ }^{44}$ - in which the Supreme Court made plain its intention to rein in Rule 10b-5. Blue Chip Stamps holds that a private plaintiff must be a purchaser or seller of securities to state a claim under Rule $10 \mathrm{~b}-5,{ }^{45}$ but the opinion is notable for its skepticism regarding securities fraud class actions, which were the lawsuits affording the Second Circuit the opportunity to push the boundaries of Rule 10b-5. ${ }^{46}$ Ernst or Ernst signals a reading of Rule 10b-5 narrowly tethered to the text of $\$ 10(\mathrm{~b})$. In rejecting the argument that an allegation of negligence would establish a fraud claim under Rule 10b-5, the Court emphasized that the scope of Rule 10b5 "cannot exceed the power granted the [SEC] by Congress under $\$ 10(\mathrm{~b}) .{ }^{37}$ Blue Chip and Ernst E Ernst signaled that the Supreme Court had abandoned "flexible" construction of the sort seen in Cady, Roberts and Capital Gains to achieve "remedial purposes."

The nail in the coffin for the effort to push Rule 10b-5 into the realm of corporate governance arrived soon thereafter. Santa Fe Industries v. Green ${ }^{48}$ is the Court's most sweeping defense of state corporate law. The Second Circuit held that a short form merger authorized by Delaware law, ${ }^{49}$ which "froze out" the company's minority shareholders, violated Rule $10 b-5 .{ }^{50}$ That court held that "no allegation or proof of misrepresentation or nondisclosure [was] necessary" to state a violation of Rule $10 \mathrm{~b}-5$; a breach of fiduciary duty was sufficient. ${ }^{51}$ Rule 10b-5 was completely divorced from disclosure. Moreover, that breach of fiduciary duty arose out of federal, rather than state, common law. ${ }^{52}$

In reversing the Second Circuit, Justice Byron White held for the Court that fraud requires a misrepresentation or nondisclosure. ${ }^{53}$ That was sufficient to answer the question presented, but White went out of his way to defend the role of state corporate law:

The reasoning behind a holding that the complaint in this case alleged fraud under Rule 10b- 5 could not be easily contained ... The result would be to bring within the Rule a wide variety of corporate conduct traditionally left to state regulation ... this extension of the federal securities laws would overlap and quite possibly interfere with state corporate law. Federal courts applying a "federal fiduciary principle" under Rule 1ob-5 could be expected to depart from state fiduciary standards at least to the extent necessary to ensure uniformity within the federal system. Absent a clear indication of congressional intent, we are reluctant to federalize the substantial portion of the law of corporations that deals with transactions in securities, particularly where established state policies of corporate regulation would be overridden..$^{54}$

43 Blue Chip Stamps v. Manor Drug Stores, 421 U.S. 723 (1975).

44 Ernst of Ernst v. Hochfelder, 425 U.S. 185 (1976). $\quad{ }^{45}$ Blue Chip Stamps, 421 U.S. at 754-755.

46 Blue Chip, 421 U.S. at 739 ("litigation under Rule 10b-5 presents a danger of vexatiousness different in degree and in kind from that which accompanies litigation in general" and the risk that the threat of enormous discovery costs could produce " in terrorem' settlements").

47 Ernst d Ernst, 425 U.S. at 214. $48 \quad 430$ U.S. 462 (1977).

49 Del. Code Ann. tit. 8, \$253 (1974).

50 Green v. Santa Fe Indus., Inc., 533 F.2d 1283, 1299 (2d Cir. 1976). $\quad{ }^{51}$ Id. at 1287.

52 Id. at $1286 . \quad 53$ Santa Fe Indus., Inc. v. Green, 430 U.S. 462, 473-474 (1977).

54 Santa $\mathrm{Fe}, 430$ U.S. at 478-479 (citations and footnotes omitted). 
Thus, the Supreme Court was emphatic in drawing a line in the sand to preserve state corporate law from lower federal courts developing their own "federal corporate law."

A decade later, the Court did not hesitate to reaffirm the line between state corporate law and federal securities law when a wave of hostile takeovers reached its zenith in the 1980 s. $^{55}$ The states were taking the lead in discouraging takeovers. The SEC was in the opposing corner, attempting to use federal law to head off state efforts to restrict the market for corporate control. ${ }^{56}$ Once again, the Supreme Court came down firmly on the side of states' control over corporate governance.

In CTS Corp. v. Dynamics Corp. of America, ${ }^{57}$ the Indiana anti-takeover statute at issue required a potential acquirer (defined as anyone acquiring certain threshold percentages of the company's shares) to obtain the approval of a company's "disinterested" shares (defined as shares not owned by the acquirer or management) before it would be allowed to vote its own shares. ${ }^{58}$ Thus, a hostile tender offeror could not use its voting power to remove incumbent management without the approval of the company's independent shareholders. The Indiana statute was limited to corporations organized under the law of Indiana, with their principal place of business and a substantial shareholder presence in that state. ${ }^{59}$

In upholding the statute against twin challenges based on the Dormant Commerce Clause and preemption under the federal securities law, the Court emphasized that state authority over voting rights was supported by tradition: "No principle of corporation law and practice is more firmly established than a State's authority to regulate domestic corps, including the voting rights of shareholders. ${ }^{\text {"0 }}$ By implication, the SEC's authority in this area was doubtful absent explicit legislative authorization. ${ }^{61}$ As far as the Supreme Court was concerned, corporate governance was a topic for the states, not the SEC.

In some tension with these decisions rebuffing "federal corporate law" is the Supreme Court's insider trading decision in Chiarella v. United States.$^{62}$ Justice Lewis Powell, writing for the Court, construed Cady, Roberts and Texas Gulf Sulphur and its progeny in the Second Circuit narrowly, fitting those decisions into a common law framework, but that

55 Patrick A. Gaughan, Mergers, Acquisitions, and Corporate Restructurings 44-49 (3d ed. 2002) (collecting statistics on the incidence of hostile takeovers).

56 Tender Offer Reform Act of 1984, H.R. 5693, 98th Cong. (1984) (proposing, at the SEC's urging, that the Williams Act be expanded to give the SEC jurisdiction over anti-takeover devices).

57481 U.S. 69, 73-74 (1987). $\quad 58$ Id.

59 Ind. Code $\$ 23-1-42-4(a)$ (1986), quoted in CTS, 481 U.S. at 72-73. $\quad{ }^{60}$ CTS, 481 U.S. at 89.

61 The limits on the SEC's authority over corporate governance were reinforced by D.C. Circuit's resolution of the conflict over dual-class voting stock. For over fifty years the NYSE prohibited listed companies from issuing common stock without voting rights. See Stephen M. Bainbridge, "The Short Life and Resurrection of SEC Rule 19c-4", 69 Wash. U. L. Q. 565, 569 (1991) (discussing origins of NYSE rule against non-voting common). The Nasdaq did not impose similar restrictions in its listing agreement. Id. at 575 . In the 1980 o General Motors, an NYSE company, refused to comply with the rule prohibiting nonvoting common stock, and the NYSE essentially ignored GM's defiance of the rule. Id. at 576-77 \& n. 54 . The NYSE was unwilling to enforce its rule unless the AMEX and Nasdaq prohibited the practice as well. Daniel R. Fischel, "Organized Exchanges and the Regulation of Dual Class Common Stock", 54 U. Chi. L. Rev. 119, 121 (1987). The SEC responded by adopting a rule of its own prohibiting non-voting common stock. That rule was struck down by the D.C. Circuit as beyond the Commission's statutory authority. Business Roundtable v. SEC, 905 F.2d 406 (D.C. Cir. 1990). Subsequently, the NYSE, AMEX, and Nasdaq agreed upon a rule limiting non-voting common stock. See "SEC Approves New Voting Rights Rule, Adopts Rule Streamlining SRO Regulation", 26 Sec. Reg. \& L. Rep. (BNA) 1708 (Dec. 23, 1994).

62445 U.S. 222 (1980). 
framework rested on a federal common law. ${ }^{63}$ Powell rejected a duty to the sellers because Chiarella owed them no fiduciary duty. ${ }^{64}$ The common law of fraud required a duty to the person on the other side of the transaction. ${ }^{65}$ Despite his reliance on common law principles, Powell was creating a federal fiduciary principle, not incorporating state law into federal law. Consequently, Chiarella's approach is hard to square with Justice White's rejection of a federal fiduciary standard in Santa Fe. Powell's justification for relying on fiduciary duty? "Section $10(b)$ is aptly described as a catchall provision, but what it catches must be fraud." Powell recognized that insider trading law would have implications for corporate governance, but he wanted to keep that body of law firmly rooted in disclosure, the province of federal law. Fiduciary duty provided him the doctrinal tool to confine insider trading to (somewhat) traditional notions of fraud.

\section{Capital Markets and Corporate GovernANCE}

\subsection{An International Market for Corporate Governance?}

We have seen the US market for corporate charters protected by the Supreme Court from incursions by the SEC. That market now has an international analogue. Capital markets are no longer parochial; technological changes have made the market for listings much deeper. Improvements in communication and related technologies have created an international market for stock exchange listings that resembles, in many respects, the longstanding federal market for corporate charters in the US.

Historically, issuers listed their stock for trading on one of the exchanges in the country where they principally did business. In an era when businesses are consolidating across national boundaries to create international conglomerates, the notion of a corporation having a "home" country seems increasingly archaic. Corporations, at least those of a certain size, are now citizens of the world, although they may identify for a time with the jurisdiction where their headquarters are located. Today, corporations around the world realistically can choose the location, or locations, where they want to raise capital. They can also choose where they want their common shares to trade. Corporations are not limited to their "home" country for financing and trading, and the capital-raising decision need not be linked to the listing decision.

Why not, then, list on an exchange that allowed a company to signal the quality of its corporate governance? There are obvious efficiency advantages. Disclosure of corporate governance terms will not only facilitate more accurate securities prices, but also allow investors to make better choices in allocating their investment dollars, funneling capital to better managed companies. If firms do not give credible assurances that they will not abuse their investors' trust, investors will not entrust them with their investment dollars. Companies

\footnotetext{
63 A.C. Pritchard, “United States v. O'Hagan: Agency Law and Justice Powell's Legacy for the Law of Insider Trading", 78 B.U. L. Rev. 13 (1998).

${ }^{64}$ Chiarella, 445 U.S. at 232-233. $\quad 65$ Id. at 228. $\quad 66$ Chiarella, 445 U.S. at 234-235.
} 
looking to maximize their returns when selling securities to the public will accordingly have a strong incentive to include corporate governance mechanisms valued by shareholders.

Exchanges have market incentives to promote the signal: "Self-interested stock exchange members will produce rules that investors want for the same reasons that self-interested bakers produce the kind of bread that consumers want." ${ }^{167}$ Securities markets live or die with trading volume. Broker-dealers make a substantial portion of their revenues from trading commissions; another chunk comes from trading for their own accounts. More trading by customers obviously means more commissions, but more liquid markets also enhance the profitability of broker-dealers' own trading. Exchanges attract trading volume by encouraging companies to list their shares and by encouraging investors to trade in those listed shares. These two goals are largely consistent, as companies will want to list their shares on exchanges that provide the greatest liquidity because liquidity minimizes their cost of capital. The exchanges also have a quasi-property interest in the stock prices quoted in their market. This interest effectively makes the exchanges residual claimants in the integrity of those stock prices. Thus, exchanges might compete to attract trading volume by providing a "bonding" signal to companies seeking to attract investors, if investors are more willing to trade in the stock of companies with good corporate governance.

That story provides an optimistic scenario of corporate government and securities law complementing each other. What is the practical limit of legislators and securities regulators to impose corporate governance mandates through securities laws? If capital markets provide the critical connection between the two, the answer to that question may lie with liquidity. Greater disclosure of information is associated with higher levels of liquidity. ${ }^{68}$ And there is evidence that fraud may have market-wide effects on liquidity ${ }^{69}$ So exchanges, and perhaps, securities regulators, will have incentives to regulate in areas where the connection to liquidity is clear.

Consider insider trading, one area where the SEC has had considerable success in imposing fiduciary standards on corporate insiders, with the blessing of both the Supreme Court and Congress. Economic theory and empirical evidence suggest that insider trading harms liquidity. ${ }^{70}$ Insider traders hold information advantages over outsiders. Those information asymmetries lead to trading profits-insiders buy low and sell high. To avoid the corresponding trading losses, outsiders would prefer to trade only with other outsiders. Securities markets are anonymous, however, so outsiders have no way of knowing when they are trading with an insider, but they do know that they will systematically lose when they do so. Market makers who supply liquidity to the markets on an uninformed basis will increase their spreads to reflect the possibility of dealing with an insider, converting insider trading into a transaction cost of all trading. Uninformed shareholders will discount the amount that they are willing to pay for shares by their expected losses from trading with insiders;

\footnotetext{
67 Mahoney, supra note 12, at 1459.

68 Frank L. Heflin et al., "Disclosure Policy and Market Liquidity: Impact of Depth Quotes and Order Sizes", 22 Contemporary Accounting Research 829 (2005).

69 Panjak K. Jain et al., "The Sarbanes-Oxley Act of 2002 and Market Liquidity", 43 Fin. Rev. 361-82 (2008) (showing that market liquidity deteriorated following Enron and related scandals, and improved after the adoption of Sarbanes-Oxley).

70 See, e.g., Louis Cheng et al., "The Effects of Insider Trading on Liquidity", 14 Pacific-Basin Fin. J. 467 (2006).
} 
they may attempt to avoid losses from trading with insiders by trading less frequently. Less trading means less liquidity, and less liquid securities markets raise the cost of trading. In this scenario, the SEC's effort to harness fiduciary principles in the service of promoting liquidity deftly walks the line where corporate governance and securities law intersect.

Policy makers recognize that encouraging liquid securities markets will facilitate capital formation, and thus, economic growth. Unfortunately, politicians are unlikely to worry about the details of promoting economic growth during a bull market. The capital markets are not crying out for government intervention when investors' primary focus is counting their gains. Bear markets, however, inevitably follow bull markets. Corporate mismanagement and corruption can be obscured by rising stock prices, but the dirty laundry has a way of surfacing in bear markets. The bad news produces dissatisfied investors who clamor for government intervention, and politicians shake off their apathy and suddenly become profoundly interested in securities law. This dynamic means that demands for regulation will arise in times of crisis, particularly if that crisis spills over into the real economy. Politicians will want to "do something," even if the proposed something has scant connection to the promotion of liquid securities markets. Corporate governance may fit the bill, providing a salient response to the scandals arising during the crisis.

\subsection{The US Competes}

The recent history of securities regulation in the US illustrates the phenomenon. For a time, proponents of the US securities law regime argued that its rigor gave US exchanges a competitive edge by allowing them to provide a bonding signal. Foreign companies could signal their integrity by exposing themselves to the demands of the US disclosure and enforcement regime, which proponents claimed was the best in the world. ${ }^{71}$ That regime permitted foreign companies to credibly pre-commit to limit self-dealing transactions, a concern that might be particularly salient in jurisdictions where controlling shareholders are common, i.e., most jurisdictions other than the US and the UK. Companies headquartered in jurisdictions not known for the quality of their legal systems might be particularly interested in the possibility of buying a credible "bonding" signal; it might be difficult or impossible for such companies to duplicate such a signal on their own. ${ }^{72}$ The power of contract goes only so far if enforcement mechanisms are dubious.

Critically, the mechanism for the precommitment signal was not a corporate governancestyle ban on such transactions, which might have been unworkable for companies in countries where cross shareholdings are common. Instead, the tool of choice was disclosure requirements under exacting US standards, backed by the threat of SEC scrutiny. The US exchanges' computerized surveillance systems also promised real teeth for enforcing insider trading rules and other prohibitions against market manipulation. Other countries have followed the US lead in prohibiting insider trading, but enforcement of those

\footnotetext{
${ }^{71}$ See generally John C. Coffee, Jr., "Racing Towards the Top?: The Impact of Cross-Listings and Stock Market Competition on International Corporate Governance", 102 Colum. L. Rev. 1757 (2002).

72 Edward Rock, "Securities Regulation as a Lobster Trap: A Credible Commitment Theory of Mandatory Disclosure", 23 Cardozo L. Rev. 675 (2002); see Michael Spence, "Job Market Signaling", 87 Q. J. Econ. 355 (1973) (outlining economic theory of signaling).
} 
prohibitions pales in comparison to the SEC's vendetta against the abuse. Of equal significance for companies listing in the United States, misstatements about a company's fortunes would be subject to the sting of SEC enforcement, generally regarded as a step above other jurisdictions, both in the probability and size of sanctions. ${ }^{73}$

In response to lobbying by the exchanges, the SEC encouraged foreign companies to list in the US by relaxing a number of potentially expensive requirements for listing. ${ }^{74}$ The SEC did not, however, go so far as to allow foreign companies to merely comply with the disclosure requirements of their home jurisdictions (a "mutual recognition" regime). From the SEC's perspective, US disclosure standards were superior; they could be tinkered with around the edges, but wholesale waiver was not an option. Although the SEC was anxious to bring foreign companies to US exchanges, it recognized that it bore a "significant political risk" from financial scandals involving foreign firms if American retail investors incurred substantial losses. ${ }^{75}$ Moreover, the SEC did not exempt foreign companies from the anti-fraud rules, with their potential for both SEC enforcement, but also, the risk of private litigation, unheard of in other jurisdictions until very recently. Companies willing to face this risk by listing in the United States sent a strong signal of honesty and integrity.

The twin burdens of SEC disclosure requirements and exposure to securities class actions made listing in the United States a costly proposition for foreign companies, notwithstanding the SEC's efforts at accommodation. The fact that a significant number of companies were willing to pay this price allowed the SEC to tell a happy story of a race to the top in the competition for international listings. The best companies-world-class companies-sought to list in the United States because it had the best regulation, the story went. Evidence of a listing premium for companies selling shares in the United States strongly supported the SEC's account. ${ }^{76}$

\subsection{The US Loses its Lead}

The cheery equilibrium between corporate governance and listing in the US has since proved to be fragile. The flow of foreign companies coming to the US stopped, and more worryingly,

73 John C. Coffee, Jr., "Law and the Market: The Impact of Enforcement", 156 U. Pa. L. Rev. 229, 238 n.17 (2007) (summarizing LSE's treatment of foreign issuers). The probability of SEC enforcement against foreign issuers cross-listing in the U.S. was probably overstated. See Jordan Siegel, "Can foreign firms bond themselves effectively by renting U.S. securities laws?", 75 J. Fin. Econ. 319, 342 (2005) (finding that the SEC averaged two enforcement actions per year against cross-listed firms).

74 Most notably, the agency: (1) allowed foreign issuers to reconcile their accounts with U.S. generally accepted accounting principles, rather than requiring a new set of financial statements prepared in accordance with US standards (see SEC Form F-1); (2) relaxed certain reporting requirements (17 C.F.R. $\$ 240.13 a-13(b)(2)$ (2009) (exempting foreign issuers from quarterly reporting requirements); Id. $\$$ 243.101(b) (exempting foreign issuers from Regulation FD's equal access to disclosure requirements); and (3) exempted foreign companies from the short-swing insider trading rule of Section 16 of the Exchange Act and the proxy requirements (17 C.F.R. $\$ 240.3$ a12-3).

75 Ethiopis Tafara \& Robert J. Peterson, "A Blueprint for Cross-Border Access to U.S. Investors: A New International Framework", 48 Harv. Int'l. L. J. 31, 49 (2007).

76 See Craig Doidge et al., "Why are Foreign Firms Listed in the U.S. Worth More?", 71 J. Fin. Econ. 205 (2004). 
reversed. After the SEC relaxed standards for foreign companies wanting to delist, ${ }^{77}$ a flood of companies headed for the doors. ${ }^{78}$

What derailed the US-led race to the top? The answer is politics, and more particularly, Congress. The dividing line between securities law and corporate governance drawn by the Supreme Court limits the SEC and the lower courts, but it does not constrain Congress. Nonetheless, for nearly fifty years after PUHCA had begun to dwindle, Congress generally respected that line. The securities laws were about disclosure.

The major exception to the disclosure focus of the securities laws was the enactment of the Foreign Corrupt Practices Act (FCPA) in 1977. The FCPA is a response to Watergate-era scandals involving the bribery of foreign officials by US companies, which came under the SEC's purview because companies were not recording the bribes and slush funds in their accounts (Surprise!). The FCPA includes a variety of books and records provisions intended to improve the accuracy of corporate disclosures, so some of its provisions are squarely within the bailiwick of the SEC. The FCPA, however, also includes a substantive provision outlawing payments by US companies to foreign officials, which can be enforced civilly by the SEC and criminally by the Justice Department. The provision sits oddly amidst the disclosure-oriented provisions of the securities laws, but its practical import has been limited until recent efforts to increase enforcement. Moreover, although it does contain a substantive provision that limits the conduct of corporations, it is not limited to public corporations, the traditional concern of the securities laws, but rather, US corporations generally. More importantly, the prohibition is outward directed. The law prohibits bribing foreign government officials. It says nothing about bribing company officers, which would be a classic corporate governance problem. Thus, the FCPA departs from the disclosure focus of the securities laws, but not in a direction that one could fairly criticize as an incursion into the state's domain of corporate governance.

More recently, however, Congress has made substantial inroads into corporate governance through amendments to the securities laws, blurring the line separating the two. Those forays by Congress into corporate governance correspond with the demise of the US as a listing destination. The first salvo of incursions into the field of corporate governance came with the Sarbanes-Oxley Act fueled by accounting scandals at Enron and WorldCom. ${ }^{79}$ Collecting a hodge-podge of reforms, Congress (1) took over the regulation of accounting firms from the private sector ${ }^{80}(2)$ imposed expensive internal controls and certification requirements; ${ }^{81}$ and (3) adopted an array of new sanctions. ${ }^{82}$ The most expensive of these requirements were standards relating to internal accounting controls, requiring both review and certifications of those controls by the chief executive officer and chief financial officer. ${ }^{83}$

\footnotetext{
77 Termination of a Foreign Private Issuer's Registration of a Class of Securities Under Section 12(g) and Duty to File Reports Under Section 13(a) or 15(d) of the Securities Exchange Act of 1934, Exchange Act Release No. 34-55540, 90 SEC Docket 860 (Mar. 27, 2007).

${ }^{78}$ Comm. on Capital Mkts. Regulation, Summary of Competitiveness Measures (2009) (noting that more than $12 \%$ of foreign firms listed on the NYSE delisted during the first 10 months of 2007); see also Craig Doidge et al., "Why Do Foreign Firms Leave U.S. Equity Markets?", 65 J. Fin. 1507 (2010) (finding that departing firms had lower growth prospects and capital requirements).

79 Pub. L. No. 107-204, 116 Stat. 745 (codified in scattered sections of $11,15,18,28$, and 29 U.S.C.).

80 Sarbanes-Oxley Act $\$ \$ 101-109,15$ U.S.C. $\$ \$ 7211-7219 . \quad 81$ Id. $\$ 302,15$ U.S.C. $\$ 7241$.

82 E.g., id. $\$ 906,18$ U.S.C. $\$ 1350 .{ }_{83}$ Id. $\$ 404(a), 15$ U.S.C. $\$ 7262(a)$.
} 
Foreign company executives proved less than enthusiastic about the spotlight afforded by those certifications, perhaps helping to speed the exodus that followed.

Not surprisingly, Congress also sought to improve corporate governance relating to the auditing function. Sarbanes-Oxley mandates that the retention, compensation, and oversight of the company's external auditor must be entrusted to an audit committee of the board of directors. The auditors must report to the audit committee "critical accounting policies and practices." The audit committee is also charged with establishing procedures for dealing with complaints relating to auditing and internal controls. These provisions are intended to set up audit committees as an independent power center within the governance structure of public corporations.

That independence is bolstered by additional mandates relating to the audit committee's composition. Audit committees must be made up exclusively of independent directors, meaning that the only compensation the director can receive from the company is the director's fee-no consulting or other employment arrangements are permitted. ${ }^{84}$ The SEC has bolstered this independence requirement by requiring companies to disclose whether any member of the audit committee qualifies as a "financial expert," which requires either experience as an accountant or an accounting officer, or experience supervising an accounting officer or overseeing public accountants. ${ }^{85}$ Listing requirements for the NYSE and Nasdaq now require financial literacy for all audit committee members.

These minor incursions into corporate governance in the Sarbanes-Oxley Act coincided with the exodus of foreign companies from US exchanges described above. Far from being chastened by that trend, Congress demonstrated even less restraint when it came to "do something" in response to the next financial crisis. This time, with the Dodd-Frank Act, the corporate governance mandates have no connection whatsoever to liquidity. ${ }^{86}$ For example, the Dodd-Frank requires that companies disclose whether the same person holds both the $\mathrm{CEO}$ and Chairman of the Board positions, and explain why the position is combined or not. ${ }^{87}$ This is a pure corporate governance provision, styled as a disclosure mandate, but with no possible connection to liquidity. It simply uses disclosure to put a thumb on the scale toward Congress's view of best corporate governance practices.

Other mandates are more explicitly driven by a political agenda. Most blatant is DoddFrank's mandate relating to conflict minerals. Concerned about violence in the Democratic Republic of Congo relating to a variety of resource extraction industries, Congress decided to use its leverage over corporate disclosure policies to deal with the problem. ${ }^{88}$ The SEC adopted a new disclosure form, Form SD, requiring companies to disclose payments in excess of $\$ 100,000$ made to governments for the purpose of commercial development of natural resources. ${ }^{89}$ The target was armed groups that were profiting from extortion of mining operations. The teeth of the rule were provided by the requirement that firms investigate and disclose if their products used any "conflict minerals." The expense of the investigation was calculated to be enormous: the SEC estimated that the total costs of the final rule would be

\footnotetext{
${ }^{84}$ Securities Exchange Act of $1934 \$ 10 A(m), 15$ U.S.C. $\$ 78 j-1(m)(2006)$.

${ }^{85}$ Regulation S-K, Item 309.

${ }^{86}$ Dodd-Frank Wall Street Reform and Consumer Protection Act, Pub. L. No. 111-203, 124 Stat. 1376 (relevant parts codified at 15 U.S.C. $\$ \$ 8 \mathrm{~m}(\mathrm{p}), 78 \mathrm{~m}$ ) (2010)).

87 Section 972, Dodd-Frank Act. $\quad{ }_{88}$ Section 1504, Dodd-Frank Act.

8977 Fed. Reg. 56,274, 56,277-278 (Sept. 12, 2012) (codified at 17 C.F.R. $\$ \$ 240.13 p-1,249$ b.400).
} 
$\$ 3$ billion to $\$ 4$ billion initially, and $\$ 207$ million to $\$ 609$ million annually thereafter. ${ }^{90}$ The benefits of the rule? Hard to calculate, according to the SEC, because it was hard to quantify peace and stability in the Congo. ${ }^{91} \mathrm{It}$ is not hard to guess, however, the benefit to investors from these disclosures, which are presumably zero.

Somewhat more closely tied to corporate governance are Dodd-Frank's mandates relating to executive pay, an issue with apparently evergreen populist appeal. The political agenda is quite clear in Dodd-Frank's requirement that companies disclose the ratio of their CEO's pay to that of their median employee. ${ }^{92}$ On the governance side, the Dodd-Frank Act requires the SEC to direct, by rule, the securities exchanges to prohibit the listing of any equity securities of public companies unless the compensation committees of the public companies' boards are made up exclusively of independent directors. ${ }^{93}$ The independence requirement for the board compensation committee parallels the independence requirement for the board audit committee. Moreover, Dodd-Frank imposes a variety of responsibilities on compensation committees, such as the hiring and supervision of compensation consultants.

The Dodd-Frank Act also enhances shareholder power over executive compensation. Public companies are now required to conduct an advisory vote of shareholders on the pay packages of top executives at least once every three years. ${ }^{94}$ "Golden parachute" payments made to executives displaced in connection with mergers and acquisitions also require an advisory vote of shareholders. In connection with these advisory votes, the SEC has enhanced the disclosure requirements for these executives in the Compensation Discussion and Analysis section of the proxy statement. That disclosure now must also address whether (and if so, how) the company has considered the results of the most recent say-on-pay vote in determining compensation policies and decisions. Shareholders are not allowed to dictate the pay packages of senior executives, but the new regime attempts to maximize the leverage implicit in embarrassment. ${ }^{95}$

The Dodd-Frank Act also attempted to shift power to shareholders by ensuring access to the company's proxy. Historically, outside insurgents could launch a full-blown contest with their own proxy statement to elect a competing slate to a company's board of directors, but such contests are costly and correspondingly rare. The Dodd-Frank Act authorized the SEC to allow shareholders to nominate candidates for director directly on the company's proxy without going to the trouble and expense of a proxy contest using a separate proxy statement. ${ }^{96}$ The SEC attempted to implement proxy access through Rule 14a-11. Rule 14a-11

\footnotetext{
90 Id. at 56,334 91 Id. at 56,350. 92 Section 953, Dodd-Frank Act.

93 Section 952, Dodd-Frank Act. The SEC has implemented this requirement through Exchange Act Rule 10C-1.

${ }^{94}$ Exchange Act $\$ 14 \mathrm{~A}$; Rule 14a-21(a).

95 The initial results of the say on pay votes that occurred immediately after the enactment of the Dodd-Frank Act showed that shareholders were approving the compensation packages for $98.5 \%$ of the companies. Even though almost all say on pay votes to date have resulted in approval of executive compensation, the mere prospect of a say on pay vote may change the amount and form (e.g., base pay versus incentive pay) of pay presented to shareholders for a vote. A number of companies, moreover, were able to secure approval only after modifying their compensation packages. The relative lack of impact for this provision is consistent with experience in the UK, which provided the model for the provision. See Jeffrey N. Gordon, "'Say on Pay': Cautionary Notes on the U.K. Experience and the Case for Shareholder Opt-in”, 46 Harv. J. Legis. 323 (2009).

96 Section 971, Dodd-Frank Act.
} 
allowed shareholders (and shareholder groups) who have held at least $3 \%$ of the company's stock for three years the right to nominate directors and have those nominees included in the company's proxy statement and ballot. The rule did not provide an alternative to a fullfledged proxy contest, however, as shareholders were limited to nominating candidates for only $25 \%$ of the board. The SEC adopted Rule 14a-11 over the heated objections of corporate management. Groups representing management then challenged the rule in court, and in mid-2011, the D.C. Circuit vacated Rule 14a-11. ${ }^{97}$ The SEC has not been stripped of its rulemaking authority, however, so it is a matter of time before it returns to the topic.

The net effect of the Sarbanes-Oxley and Dodd-Frank Acts has been to erode the traditional line between securities law and corporate governance in the US. The key word is "traditional"; there has not been any legal barrier to Congress taking over the governance of public corporations since the 1940s. Perhaps what is surprising is that the incursion took as long as it did. Perhaps less surprising is that Congress now appears completely indifferent to the status of the US as a listing destination. Competitiveness in financial services, once a hot topic, was swept aside as a concern in the rush to respond to accounting scandals and a financial crisis. Also swept aside has been the notion that there "should" be a dividing line between corporate governance and securities law.

\section{Conclusion}

The US maintained the dividing line between corporate law and securities law for nearly 70 years after the adoption of the federal securities law. Much of the work done protecting that line was done by the Supreme Court, which affirmed the role of the states in corporate law as a matter of tradition, rather than enforcing strict constitutional limits. The last 15 years, however, have seen that line beginning to erode as Congress has amended the federal securities laws to include corporate governance mandates with little or no connection to liquidity, the traditional focus of securities regulation. Those intrusions were responses to accounting scandals and financial crisis. Congress's interventions in corporate governance have coincided with a decline in the competitiveness of the US in the market for listings, but Congress has not responded to that decline, which is not salient enough to rise to "crisis" level.

To be sure, the US's decline as a listing destination cannot wholly be ascribed to Congress. Another factor fueling the trend has been the continuing development of trading technology and market liquidity that once promised to fuel the US's race to the top. The comparative advantage of US exchanges has now been substantially eroded. Stock exchanges around the world now offer similar speed in executing orders. Increasingly, securities trading has been reduced to the status of commodity. The best trading systems are no longer the monopoly of the exchanges, which are hemorrhaging market share to proprietary trading systems and dark pools. ${ }^{98}$ Commodification of trading technology-along with greater access

97 Business Roundtable v. S.E.C., 647 F.3d 1144 (D.C. Cir. 2011).

98 See generally Jerry W. Markham \& Daniel J. Harty, "For Whom the Bell Tolls: The Demise of Exchange Trading Floors and the Growth of ECNs", 33 J. Corp. L. 865 (2008). 
to information about companies in other jurisdictions-has greatly reduced the liquidity advantages historically enjoyed by the NYSE, which has cut fees in response. ${ }^{99}$

Of equal importance to the question of liquidity is the fact that companies no longer need to bring their shares in physical proximity to investors. Institutional investors can access virtually any market in the world. ${ }^{100}$ As a result, ADRs have fallen out of favor, as investors invest directly abroad. ${ }^{101}$ Moreover, Rule $144 \mathrm{~A}$ allows issuers to access capital in the United States without a US listing. ${ }^{102}$ Why should a company pay for an expensive listing in New York if a listing in their home country allows them easy access to capital from around the world? For regulators, this means that listing requirements are likely to offer little leverage as a regulatory tool. Draconian mandates, unrelated to liquidity, will be met by an exodus to jurisdictions with more lenient standards.

Another threat to the use of listing standards as a means of promoting corporate governance reform is private equity. The rise of private equity has demonstrated that firms in many industries with diverse business models can thrive without access to public capital markets. For these firms, corporate governance is purely a matter of contract. Firms that value liquidity are likely to tolerate disclosure mandates relating to liquidity, but if securities law and disclosure mandates drift toward corporate governance imperatives unrelated to liquidity, firms are likely to exit the public markets. If Congress continues to intervene in corporate governance, the number of US public companies could dwindle.

The US experience thus presents a cautionary tale for reformers contemplating the use of securities law to upgrade corporate governance standards. Countries may vary, however, in the relationship that corporate governance has to liquidity. Lessons from the US experience may have limited relevance for other parts of the world: US corporate governance is pretty good, so marginal improvements in any particular aspect may have limited real-world effects. ${ }^{103}$

The situation may be quite different in developing economies, where the baseline may not be as high. For example, there is evidence that degree of board independence and splitting the roles of Chair and CEO may correlate with greater liquidity post-IPO for Chinese firms. ${ }^{104}$ These correlations may be explained by the prevalence of controlling shareholders in Chinese firms, and perhaps, relatively weak legal enforcement. The Chinese experience may be singular in another way-many governance reforms in that country are initiated by the country's securities regulator, which may be forced to act due to the absence of any

99 Jacob Bunge, NYSE Adjusts Charges In Bid to Draw Traders, Wall St. J., Feb. 4, 2009, at C5 ("Incumbent stock exchanges are grappling with lower year-on-year trading volumes and tougher competition from newer entrants like BATS Exchange and Direct Edge in the U.S., and a host of trading platforms in Europe").

100 Chris Brummer, "Stock Exchanges and the New Markets for Securities Laws", 75 U. Chi. L. Rev. 1435, 1459-66 (2008).

101 See Eric J. Pan, "Why the World No Longer Puts Its Stock in Us" 8-11 (Benjamin N. Cardozo School of Law, Working Paper No. 176, 2006).

10217 C.F.R. $\$ 230.144 \mathrm{~A}(2009)$ ). On the importance of Rule 144A in undermining the incentive of foreign issuers to list in the U.S., see Pan, supra note 101, at 7. See also William K. Sjostrom, Jr., "The Birth of Rule 144A Equity Offerings", 56 UCLA L. Rev. 409 (2008).

103 Jeffrey N. Gordon, “The Rise of Independent Directors in the United States, 1950-2005: Of Shareholder Value and Stock Market Prices", 59 Stan. L. Rev. 1465, 1469 (2007).

104 Junheng Zhu et al., "Ownership Structure, Corporate Governance and IPO Post-Listing Liquidity", Queensland University Working Paper, 2014. 
alternative actor. ${ }^{105}$ In countries such as China, where the rule of law is not as well established, the move toward mandating better corporate governance standards may substantially improve the operation of the capital markets, even absent an obvious connection between corporate governance and liquidity.

Another consideration for corporate governance reformers is that familiarity may breed liquidity. Standardization may be an important feature in corporate governance if information is incomplete and market participants are boundedly rational. If investors understand a common governance structure, making it mandatory may allow for easier comparability, which may be particularly important to firms seeking overseas investment. From the US perspective, the prevalence of Delaware as the choice of incorporation for most public companies in the US is sometimes attributed to investors' preference for Delaware incorporation-which may be based on Delaware's prevalence. Institutional investors are familiar with Delaware corporate law; they know what they are getting. Sometimes having a consistent standard is more important than having the best standard, or the standard best tailored for a particular firm.

On the other hand, a standardization strategy may have long-term consequences. Once standards become prevalent, if not universal, in the marketplace, politicians may be tempted to mandate the prevalent standard as "best practice." Once mandated, however, there may be costs imposed on firms that deviated from the norm for idiosyncratic, but perhaps legitimate reasons. In addition, the mandate may stifle experimentation and adaption to new conditions. Assessing the benefits and costs flowing from standardization is a daunting empirical task, particularly because the incidence of those benefits and costs is unlikely to be evenly distributed.

This chapter has focused on the connections between corporate governance, capital markets, and securities law. Looking at how the relation among these has developed over time in the US, it has identified liquidity as the key variable connecting the three. Corporate governance mandates with a clear connection to liquidity are more likely to be accepted and to last. When policy makers move beyond the promotion of liquidity, firms may choose to exit to avoid costly mandates.

105 Nicholas Calcina Howson, “ 'Quack Corporate Governance' as Traditional Chinese Medicine-the Securities Regulation Cannibalization of China's Corporate Law and a State Regulator's Battle Against Party State Political Economic Power", Working Paper, University of Michigan, 2014. 